\title{
Pig-islet xenotransplantation: recent progress and current perspectives
}

\author{
Hai-Tao Zhu, Wan-Li Wang, Liang Yu and Bo Wang* \\ Department of Hepatobiliary Surgery, First Affiliated Hospital, Medical College, Xi'an Jiaotong University, Xi'an, China
}

Edited by:

Hesham Abdeldayem, National Liver

Institute, Egypt

\section{Reviewed by:}

Nuala Mooney, Centre National de la

Recherche Scientifique, France

Kun-Ming Chan, Chang Gung

Memorial Hospital at Linkou, Taiwan

Sherif Mohamed Saleh, National Liver

Institute, Egypt

Bassem Soliman Hegab, National

Liver Institute, Egypt

*Correspondence:

Bo Wang, Department of Hepatobiliary Surgery, First Affiliated

Hospital, Medical College, Xi'an

Jiaotong University, No. 277 West

Yanta Road, Xi'an 710061, China

e-mail: bobwang75@126.com
Islet xenotransplantation is one prospective treatment to bridge the gap between available human cells and needs of patients with diabetes. Pig represents an ideal candidate for obtaining such available cells. However, potential clinical application of pig islet still faces obstacles including inadequate yield of high-quality functional islets and xenorejection of the transplants. Adequate amounts of available islets can be obtained by selection of a suitable pathogen-free source herd and the development of isolation and purification method. Several studies demonstrated the feasibility of successful preclinical pigislet xenotransplantation and provided insights and possible mechanisms of xenogeneic immune recognition and rejection. Particularly promising is the achievement of long-term insulin independence in diabetic models by means of distinct islet products and novel immunotherapeutic strategies. Nonetheless, further efforts are needed to obtain much more safety and efficacy data to translate these findings into clinic.

Keywords: islet, pig, isolation, xenotransplantation, immune, rejection

\section{INTRODUCTION}

Diabetes is one of the most dangerous threats to human health. However, pancreatic islet transplantation has gradually showed satisfactory and prospective application in the treatment of type 1 diabetes mellitus (T1DM) (1). In the year 2000, Edmonton protocol (2) demonstrated that islet allotransplantation had achieved a remarkable success, but shortage of donors still prevented the progression of clinical islet transplantation. Xenotransplantation provides an effective and appropriate solution for this limitation. Among the potential candidates for islet xenotransplantation, pig is considered as the most ideal donor for future clinical applications (3-8). Although encouraging findings have been obtained in pig-to-primate islet xenotransplantation $(9-11)$, the potential clinical application of pig islet still faces two major challenges: inadequate supply of islet cells with high-quality and xenorejection. This review will discuss the current approach and progress in pig donor selecting, isolation and preparation of pig-islet grafts, prevention of xenorejection, microbial safety, and obtained findings of clinical trials.

Abbreviations: $\quad \alpha 1,3 \mathrm{GT}, \quad \alpha 1,3$-galactosyltransferase; $\alpha$-Gal, $\quad$ Gal $\alpha 1-3 \mathrm{Gal} \beta 1-$ 4GlcNAc-R; APCs, antigen presenting cells; APIs, adult pig islets; CMS, Chicago Medical School; CTLA4Ig, cytotoxic T lymphocyte antigen 4-immunoglobulin; ECs, endothelial cells; GMP, good manufacturing practices; GT-KO, $\alpha 1,3-$ galactosyltransferase gene-knockout; HAR, hyperacute rejection; H-D antigen, Hanganutziu-Deicher antigen; IBMIR, instant blood-mediated inflammatory reaction; ICCs, islet-like cell clusters; IE $/ \mathrm{mm}^{2}$, islet equivalents per $\mathrm{mm}^{2}$; IEQ, islet equivalents; MSCs, mesenchymal stem cells; NK cell, natural killer cell; NHPs, non-human primates; NPIs, neonatal pig islets; PERV, porcine endogenous retroviruses; SPF, specific pathogen-free; T1DM, type 1 diabetes mellitus; TCR, T-cell receptor; WIT, warm ischemia time.

\section{ORIGINAL OF PORCINE ISLETS}

Islets obtained from embryonic, fetal, neonatal, young, or adult pigs have been selected as the grafts for xenotransplantation. Despite several years of study, no exact consensus has been achieved about the selection of the most optimal pig to supply adequate viable isolated islet cells for preclinical xenotransplantation $(11,12)$. Only islet xenografts harvested from neonatal (2-3 days old) and adult ( $>6$ months) pigs have been shown to correct diabetes in non-human primates (NHPs) or humans (13-16).

Fetal pig islet-like cell clusters (ICCs) and neonatal pig islets (NPIs) are immature cells, which can be easily obtained by enzymatic digestion and simple culture. Other advantages of ICCs and NPIs are their apparent resistance to ischemic and inflammatory damage during isolation that makes islet recovery more efficient. However, several studies suggested that ICCs had poor insulin response to glucose (17-21), Typically, ICCs requires 2-3 months for maturation to achieve in vivo functionality (22). Additionally, in diabetic monkeys, transplanted pig ICCs were almost completely destroyed within 12 days post-transplantation (23). All the disadvantages restrict the potential clinical application of pig ICCs.

Neonatal pig islets consist of differentiated pancreatic endocrine cells (about 35\%) and primarily epithelial cells (about $57 \%)$, which is also considered as islet precursor cells $(24,25)$. NPIs are more responsive to high glucose than ICCs and subsequently have a powerful functional ability to restore normoglycemia in diabetic animals, which are mainly due to $\beta$ cell expansion and the striking differentiation of epithelial cells into $\beta$ cell (2629). NPIs clearly express xenoantigens including sialic acid antigens, Hanganutziu-Deicher (H-D) antigens, and Gal $\alpha 1-3 \mathrm{Gal} \beta 1-$ 4 GlcNAc-R ( $\alpha$-Gal) epitopes (30). However, with the development 
of genetic engineering technology, stable gene transferred NPIs can therefore effectively attenuate the xenoantigenicity (30-32). In pig-islet xenotransplantation, several studies suggested that cell numbers in the range of 25,000-100,000 islet equivalents (IEQ) $/ \mathrm{kg}$ recipient body weight were required to achieve insulin independence in diabetic NHPs $(13,16,33-35)$. Usually, after in vitro culture, tissue from one neonate pancreas yields about 50,000 NPI aggregates (24); thus, at least four neonate pig donors are required to treat a diabetic primate weighing $6-8 \mathrm{~kg}$.

Adult pig is regarded as the major donor source of islet xenografts, which can supply a sufficient number of viable islet cells and start functioning immediately after transplantation. More than 255,000 adult pig islets (APIs) with high purity (8095\%) can be isolated from an adult pig donor (36). Furthermore, published study also reported an extremely high APIs yield, up to 800,000 IEQ per pancreas after purification (37). The achievements make it possible to perform single pig donor clinical xenogeneic transplantation. Additionally, in comparison with young pig ( $<6$ months) pancreas, a great number of large $(150-200 \mu \mathrm{m})$ and well-structured islets can be obtained from adult pig donors (38-40). In large islets, the centralized structure for both collagen and capillaries could reduce enzymatic digestion-induced islet damage and subsequently facilitate post-transplant revascularization $(38,41)$. Consequently, APIs possess a better potential for cellular engraftment in xenotransplantation.

The breed and strain of donor pigs have a vital impact on the outcome of islet isolation. Previous studies suggested that German Landrace and Large White pigs appeared to be more suitable islet donor breeds than Duroc, Pietrain, Hampshire, Belgium Landrace, local farmers (hybrid), and wild-type pigs (42, 43). The German Landraces showed the highest numbers of large islets $(150 \mu \mathrm{m})$ and islet volume density (\%) (43). In contrast, Heiser et al. reported that Pietrain pig could produce more islet yields than purebred German Landrace, Munich minipig "Troll," and hybrid pigs (44). The variability of results in different laboratories was possibly related to alterations in islet isolation and preparation procedure. Recently, very high islet yields (up to $9,589 \pm 2,838 \mathrm{IEQ} / g$ pancreas) with large size and well-function were harvested from adult Chicago Medical School (CMS) miniature pigs (45). The CMS miniature pigs can be bred under specific pathogen-free (SPF) conditions. All these making this pig breed potentially a better donor candidate for future clinical islet xenotransplantation.

\section{ISOLATION AND PREPARATION OF PORCINE ISLETS}

Islet-like cell clusters and NPIs can be easily obtained by simple enzymatic digestion and subsequent pre-transplantation culture due to relative lack of exocrine tissues and concomitant relative abundance of endocrine tissues $(23,24,46)$. Briefly, the pancreas from fetuses or neonates is surgically removed in sanitary environments, chopped into small fragment measuring 1-2 $\mathrm{mm}^{3}$, digested by collagenase, washed, and then explanted in Petri plate for culturing. Normally, a culture time of 4-9 days is required to clear exocrine cells and facilitate islet cell re-aggregation. The isolation and preparation of APIs grafts from adult pigs is similar to that of humans. Factors including quality status of donor pancreas, blood exsanguinations, warm ischemia time (WIT), perfusate, types of digestive enzyme, and isolation/purification process will affect the islet yield and function (47-49).

\section{SELECTION AND PROCUREMENT OF PANCREAS}

Morphological screening before isolation process is necessary to obtain amounts of islet cells with high-quality, decrease variance in islet yield and viability, and reduce economic costs. A rapid and inexpensive strategy for assessment of pig donor pancreas was established in 1994 (50), which indicated that a pancreas containing round or oval islets with compact borders would provide successful islet isolation. Meanwhile, islet size in situ was also regarded as another important parameter for successful isolation. A donor pancreas with predominantly large islets $(>200 \mu \mathrm{m})$ generally yielded significantly higher numbers of cell grafts $(51,52)$. Additionally, a recent study indicated that only islet equivalents per $\mathrm{mm}^{2}\left(\mathrm{IE} / \mathrm{mm}^{2}\right)$ in splenic lobe of pancreas could dramatically predict an accurate islet yield, while variables such as pig donor age, gender, ischemic time, and enzyme lot were not significantly correlated with islet yield (53).

Warm ischemia time during pancreas procurement should be reduced as much as possible to prevent autolysis of pig donor pancreas and apoptosis in islet cell, reduce expression of inflammatory mediators, and improve islet survival rate during culture $(54,55)$. However, there is still lack of uniform standards of safe WIT for pig-islet preparation. It is considered that WIT within $10 \mathrm{~min}$ was essential for successful pig-to-primate islet xenotransplantation (48).

\section{ISOLATION OF PORCINE ISLETS}

Although several major improvements or modifications have been made in the field of pig pancreas digestion and islet isolation (56-58), there is still a need for better isolation methods. Usually, immediately after harvesting of intact pig pancreas under sterile conditions, the pancreatic duct is cannulated and then collagenase is delivered by syringe or controlled perfusion after cold preservation ( $<2 \mathrm{~h}$ of cold ischemia time is advisable). Currently, a novel good manufacturing practices (GMP) grade bovine nervous tissue-free enzyme, Liberase MTF $\mathrm{C} / \mathrm{T}$, which contains lower endotoxin content $(<10 \mathrm{EU} / \mathrm{mg})$, is recommended for successful pancreas digestion $(59,60)$. Following the step of collagenase injection, the pancreas is placed in a new re-circulating digestion/filtration chamber (called Oxford chamber), which is similar to standard Ricordi chamber. The Oxford chamber results in less destruction of tissue, greater yield of islets, as well as improved cell viability (61). With the new device, up to 5,000 islets/g pancreas can be obtained from juvenile pigs. During this digestion process, another study recommended that digestion time should be limited to $35 \mathrm{~min}$ and temperature in the chamber should not exceed $35^{\circ} \mathrm{C}(62)$. The limited time and lower temperature avoid the deleterious impact of overdigestion and oxidative stress induced islet damage, respectively $(45,63)$. Once the islets are dissolved from collagen matrix, the freshly isolated cells are immediately removed from digest/filtration chamber and then placed in a cell processor (COBE 2991) for purification.

\section{PURIFICATION OF PORCINE ISLETS}

Purification is the next necessary process to completely separate islets from acinar tissues, especially for islet preparation from 
young or adult pigs. The classical purification method is based on a density gradient centrifugation, taking advantage of the fact that the density of islet is lower than that of exocrine tissue. The final purity of islet products mainly depends on the characteristics of density gradients (64). At present, Ficoll is the most commonly used reagent for islet purification $(56,65)$, and usually a purity of 70-90\% (islets/whole pancreas) can be achieved (66). However, this reagent has disadvantages of hypertonicity, high viscosity, and possible endotoxin content, which are harmful to pig-islet viability and function (67). In contrast, Iodixanol is widely used in clinical examination as an iso-osmotic contrast medium (approximately $290 \mathrm{mOsm} / \mathrm{kg}$ ), which is free of endotoxin. Compared with Ficoll solution, Iodixanol can significantly improve pig-islet yield and viability, reduce cytokine/chemokine generation, and prevent islet mass loss during pre-transplantation culture. (67-69).

In general, freshly obtained islets from adult pigs are often of heterogeneous constitution, culturing provides a valuable tool to improve xenograft quality and homogeneity (70). Although islet recovery decreased dramatically after prolonged culture (714 days), the APIs displayed shorter time-to-normoglycemia and reversed hyperglycemia in all recipients.

\section{IMMUNOLOGICAL REJECTION OF PORCINE ISLET XENOTRANSPLANTATION}

\section{INSTANT BLOOD-MEDIATED INFLAMMATORY REACTION}

Immunological rejection, which poses negative impacts on islet engraftment as well as function, is still a major obstacle for successful clinical application of pig-islet xenotransplantation $(71,72)$. Several studies showed that after intraportal injection, tissue factor (TF) produced and expressed on the transplanted pig islets would first trigger platelet accumulation, coagulation, and complement activation, neutrophil infiltration, as well as graft dysfunction and destruction when exposed to fresh recipients' blood; this phenomenon was described as instant blood-mediated inflammatory reaction (IBMIR) (73-75). Generally, IBMIR contributes to a considerable early pig-islet xenograft loss (estimated up to $60-80 \%$ ) in diabetic primate $(71,76)$. Thus, effective treatments targeting IBMIR response provide promise for minimizing the critical islet dose to restore normoglycemia and insulin independence. After IBMIR has emerged, other subsequent immune responses intervene more specifically in relation to pig-islet xenografts.

\section{HYPERACUTE REJECTION}

Islet engraftment is a process of graft revascularization mainly by recipients' endothelial cells, very few endothelial cells from donors can survive after pre-transplantation culture (77). In addition, Gal molecules expressed on pig islets are lower than solid-organs, only $5 \%$ of $\mathrm{Gal}$ is expressed on the surface of APIs and $\alpha 1,3$ galactosyltransferase $(\alpha 1,3 \mathrm{GT})$ activity was also undetectable (78, 79). Hence, the pig-islet xenografts rarely undergo hyperacute rejection (HAR) as observed in vascularized organ transplants. Furthermore, in a study of pig-to-NPH islet xenotransplantation, neither increase in Gal-specific IgG or IgM antibody levels nor Galspecific staining (isolectin B4) on islets was observed (16). All the data indicate that natural anti-Gal antibodies do not appear to play a major role in the immune rejection of APIs in diabetic NHPs. Nevertheless, Gal expression on pig islets is age dependent, both
ICCs and NPIs clearly express a relatively higher level of Gal antigens (up to $11-19 \%$ of total islets) $(30,78)$. Additionally, the Gal expression remains positive with both small $(<100 \mu \mathrm{m})$ and large islets $(>100 \mu \mathrm{m})$ after isolation procedure (41). Therefore, Gal molecules are still considerable targets for humoral xenorejection.

\section{CELLULAR REJECTION}

Still, if the islet xenografts escape the acute damages due to IBMIR and additional humoral response, they will be subject to acute cellular rejection. Typically, in pig-to-rodent islet xenotransplantation, cellular rejection appears to be mainly a $\mathrm{CD} 4^{+}$ T-cell-dependent process (80-82). In diabetic primates, the acute cellular rejection takes place during the first $24 \mathrm{~h}$ to 20 days after transplantation and is characterized by a massive infiltration of macrophages and T cells (CD4 ${ }^{+}$and $\mathrm{CD} 8^{+} \mathrm{T}$ cells) in the periphery of grafts $(16,83)$. Lindeborg et al. further demonstrated that the $\mathrm{CD}^{+} \mathrm{T}$ cells were the major phenotype of activated T-cell clones reactive against pig-islet antigens (84). Besides, the $\mathrm{T}$ cell-mediated response possibly induces numerous other cellular responses such as natural killer cell (NK cell), B cell, and innate responses. All these indicate that $\mathrm{T}$ cell plays a crucial and central role in the cellular rejection against pig islets. Although pig-islet cells are not believed to act as professional antigen presenting cells (APCs), both direct and indirect pathways of antigen presentation appear to be involved in the xenogeneic T-cell response (72). Usually, T cells require two signals to become fully activated, one is T-cell receptor (TCR) signaling, and the other is co-stimulatory signal. Co-stimulation signal, which is provided by interaction between co-stimulatory molecules expressed on the membrane of APC and T cell, is very crucial to induction and amplification of an effective immune response (85). Thus, therapies targeting different pathways affecting T-cell activation are believed to induce a long-term pig-islet survival and host hyporeactivity.

\section{METHODS TO RELIEVE XENOGENEIC REJECTION ENCAPSULATED ISLETS}

Immuno-isolation, hiding the islet grafts from recipients' immune system, has become an effective strategy to protect pig islets from immune rejection (86). Till present, there are two types of immune-isolation devices: microencapsulation and macroencapsulation. Microencapsulated islets are microcapsules containing single islet or few islets, while the macrocapsules contain a few islets. The sizes of encapsulated islet grafts should be chosen according to implant sites as well as islet viability and function. Although the microcapsules are difficult to implant and remove, the permeability of microcapsules are better than that of macrocapsules. The ideal capsules should protect inner pig grafts from attacks mediated by host's immune cells and enable free exchange of nutrients, oxygen, and wastes. Thus, the function of encapsulated islet is closely linked with biocompatibility of materials. (87). In recent years, a variety of artificial materials, including modified polysulfone, protamine-heparin complex, cellulose, agarose, ethylene glycol, and alginate were used to form macrocapsules or microcapsules, as a result, islet graft survival time was significantly prolonged (88-92). Moreover, after subcutaneous transplantation of encapsulated pig islets (alginate based), 
a 6-month correction of hyperglycemia was observed in diabetic NHPs without immunosuppression (14, 93).

Although many novel encapsulated pig islets have been developed and shown possible results in reducing xenogeneic rejection and prolonging functional graft survival time, several problems still exist before large-scale clinical, such as infectious complications, low diffusion capacity, and pericapsular fibrotic overgrowth.

\section{CO-STIMULATORY BLOCKING}

The engagement of TCR with foreign antigen without costimulatory signal will render $\mathrm{T}$ cells unresponsive to the antigen (known as T-cell anergy), thereby suppressing antigen induced response. Our previous study showed that the survival rate of donor-derived (pig) cytotoxic T lymphocyte antigen 4immunoglobulin (CTLA4Ig) gene-modified islet xenografts was significantly prolonged in diabetic rats. The possible mechanism was that the CTLA4Ig fusion protein blocked CD28/B7 co-stimulatory signaling of the primary pathway, which eventually induced differentiation bias of $\mathrm{T}$ helper cells (Th cells) (94). When the direct and indirect pathways of T-cell activation were selectively blocked by pig CTLA4Ig modified immature dendritic cells and murine CTLA4Ig protein, the survival time of pig-islet xenografts was significantly prolonged ( $>100$ days) in diabetic mice (95). Anti-CD154 antibodies, known to be effective in blocking indirect pathway of allorecognition $(96,97)$, is also a critical component of effective immunosuppressive strategies in preventing cellular rejection in pig-to-NHPs islet xenotransplantation (16, 98). However, the clinical application of anti-CD154 antibodies is restricted due to its high risk of thromboembolic complications (99). Notably, these co-stimulatory blockades have not induced immune tolerance, in which they are included in longterm immunosuppressive protocols. Similar to systemic immunosuppression, infection and morbidity are also detected in the recipients treated by co-stimulatory blocking. More specific costimulatory blockade should be conducted to improve the safety profile of tolerance induction.

\section{GENE-MODIFIED PIG IN ISLET XENOTRANSPLANTATION}

Genetically modified pigs offer a number of potential advantages in minimizing the risk of thrombosis, reducing rapid loss of transplanted islets, decreasing the number of required islets, mitigating side effects of conventional/systemic immunosuppression, and improving islets activity and survival (6, 100, 101). Transgenic expression of human heme oxygenase-1 (HO-1) can effectively protect pig xenografts from ischemia/reperfusion injury and acute rejecting mediated by inflammatory cytokines (102) Humoral rejection can be overcome in pig-to-NHPs islet xenotransplant by crossbreeding of $\alpha 1,3$-galactosyltransferase gene-knockout (GT$\mathrm{KO})$ pigs with transgenic pigs expressing human complement regulators including CD46, CD59, and human decay-accelerating factor (hDAF, CD55) (103-105). Additional pig genetic engineering, knockout of TF, and overexpressing of human antithrombotic genes (CD39/thrombomodulin), will certainly prevent the occurrence of IBMIR and coagulation dysfunction (71). Pig islet transgenic for a high-affinity variant of CTLA4Ig also displays the potential to normalize glucose homeostasis and completely prevents cellular rejection in humanized mouse model (106). Recently, the development of RNA interference technology targeting porcine endogenous retroviruses (PERV) has substantially solved the possible problem of retrovirus contamination (107, 108). With the development and modification of genetic engineering, transgenic pigs will eventually drive islet xenotransplantation into clinical application.

\section{OTHER FACTORS INFLUENCING ISLET SURVIVAL IMPLANT SITE}

Successful pig-islet xenotransplantation is also closely related with appropriate selection of implantation site. The ideal transplant site should take into account: (1) surgical operation is simple and safe, (2) the ability to maintain a stable glucose metabolism, and (3) immune protection (109). Besides intrahepatic transplantation, renal subcapsular, subcutaneous, as well as omentum are commonly used sites in both experimental and preclinical islet xenotransplantation (110-112). Renal subcapsular and omentum represent the interesting alternatives due to advantages of relatively convenient and invasive process, sufficient blood and oxygen supply (omentum), portal venous drainage (omentum), and anatomical immune privilege.

\section{ISLET GRAFT REVASCULARIZATION}

Regeneration of optimal microvascular supply is a vital prerequisite for islet transplantation (113). However, isolated pig islets are avascular and revascularization is generated 14 days after transplantation (114), therefore, promoting revascularization process and protecting newly formed microvasculature from rejectionmediated damage will immensely contribute to the improvement of islet function and survival. A recent study showed that, when islets were coated with mesenchymal stem cells (MSCs) and endothelial cells (ECs), the EC proliferation, sprout formation, migration of ECs into the islets as well as subsequent vascularization were significantly enhanced by MSCs (115). Similar findings were also demonstrated in syngeneic islet transplantation (116). Considering the powerful pro-angiogenic and immunomodulatory properties of MSCs, for pig-islet xenotransplantation, pretreatment of islet xenografts with recipient-derived MSCs will be helpful to accelerate islet revascularization and improve islet engraftment.

In addition, embryonic pig pancreatic tissue may also be another good choice. Embryonic pancreatic implants predominantly induce host-type vasculature to support growth and survival in diabetic rodents or monkeys $(112,117)$, thereby evading hyperacute or acute rejection.

\section{CLINICAL STUDY}

The systematic clinical application of pig islets was first performed by Groth group (118). Between 1990 and 1993, 10 TIDM patients with kidney allografts were transplanted pig ICCs either intraportally or under the capsule of renal graft. After transplantation, pig C-peptide could be detected in the urine for 200-400 days in four patients. The data suggest that pig islets can survive in the humans, providing a good basis for clinical use of xenogeneic islet.

The long-term pig-islet viability and function was reported by Elliott et al. (15). The blood glucose level of T1DM patient was 
significantly reduced when the alginate-encapsulated NPIs was implanted intraperitoneally. After 10 years of follow-up, biopsy showed that there were still a large number of functional islets throughout peritoneal tissue. This single case study indicates that pig islets may have a positive long-term safety and therapeutic effect in the treatment of human T1DM, suggesting the necessity to conduct more large-scale clinical studies.

Living Cell Technology Co., Ltd. (LCT) developed a commercial encapsulated pig-islet product (Diabecell), which was tested in phase I/IIa clinical study in Moscow since 2007 (119, 120). A total of seven T1DM patients received Diabecell intra-abdominally at a dosage of 5,000-10,000 IEQ/kg, no significant adverse reactions were found post-transplantation. After 2-year follow-up, five patient's blood glucose levels decreased to a normal range (5.8-8.2 $\mathrm{mmol} / \mathrm{L})$, two patients were independent with insulin administration. Additional I/IIa trials are being conducted in New Zealand.

\section{SAFETY OF PORCINE ISLET XENOTRANSPLANTATION}

Interspecies transmission of PERV is still a potential risk factor in clinical pig-islet xenotransplantation. When human HK-293 cells were co-cultured with pig cells in vitro, PERV could infect human cells (121). In addition, the possibility of cross-species transmission of PERV was also confirmed in pig-to-SCID mice islet xenotransplantation (122). In contrast, no evidence of PERV activation was found in TIDM patients after long-term follow-up (123). However, PERV remains a potential threat requiring longterm follow-up in human clinical trials. Stringent PERV screening should be conducted in clinical islet xenotransplantation. With the emergence of PERV gene-knockout pigs, this bio-safety risk will be eliminated completely.

Besides PERV infections, other pathogens including herpesvirus, pig cytomegalovirus, lymphotropic herpesvirus, as well as bacterial pathogens also pose safety problems in pig-islet xenotransplantation, highlighting the importance of selecting of SPF pigs and prescreening of donor pigs.

\section{CONCLUSION}

Building on the remarkable progress in the experimental/clinical studies, it appears that pig islets have grateful potentiality to reverse diabetes in NHPs and humans. With development of suitable sources of genetically modified pigs and modification of isolation technology, together with improvement of specific immunosuppressive methods, a tangible therapy will benefit the patients with diabetes in the very near future. However, questions remain and detailed problems need to be adequately addressed.

\section{REFERENCES}

1. de Kort H, de Koning EJ, Rabelink TJ, Bruijn JA, Bajema IM. Islet transplantation in type 1 diabetes. BMJ (2011) 342:d217. doi:10.1136/bmj.d217

2. Shapiro AM, Lakey JR, Ryan EA, Korbutt GS, Toth E, Warnock GL, et al. Islet transplantation in seven patients with type 1 diabetes mellitus using a glucocorticoid-free immunosuppressive regimen. N Engl J Med (2000) 343(4):230. doi:10.1056/NEJM200007273430401

3. Cooper DK, Gollackner B, Sachs DH. Will the pig solve the transplantation backlog? Annu Rev Med (2002) 53:133. doi:10.1146/annurev.med.53.082901. 103900

4. Koulmanda M, Qipo A, Smith RN, Auchincloss H Jr. Pig islet xenografts are resistant to autoimmune destruction by non-obese diabetic recipients after anti-CD4 treatment. Xenotransplantation (2003) 10(2):178. doi:10.1034/ j.1399-3089.2003.02040.x

5. Potter KJ, Abedini A, Marek P, Klimek AM, Butterworth S, Driscoll M, et al. Islet amyloid deposition limits the viability of human islet grafts but not porcine islet grafts. Proc Natl Acad Sci U S A (2010) 107(9):4305. doi:10.1073/pnas.0909024107

6. Tai HC, Ezzelarab M, Hara H, Ayares D, Cooper DK. Progress in xenotransplantation following the introduction of gene-knockout technology. Transpl Int (2007) 20(2):107. doi:10.1111/j.1432-2277.2006.00398.x

7. Casu A, Echeverri GJ, Bottino R, van derWindt DJ, He J, Ekser B, et al. Insulin secretion and glucose metabolism in alpha 1,3-galactosyltransferase knockout pigs compared to wild-type pigs. Xenotransplantation (2010) 17(2):131. doi:10.1111/j.1399-3089.2010.00572.x

8. Garkavenko O, Dieckhoff B, Wynyard S, Denner J, Elliott RB, Tan PL, et al. Absence of transmission of potentially xenotic viruses in a prospective pig to primate islet xenotransplantation study. J Med Virol (2008) 80(11):2046. doi:10.1002/jmv.21272

9. Cozzi E, Bosio E. Islet xenotransplantation: current status of preclinical studies in the pig-to-nonhuman primate model. Curr Opin Organ Transplant (2008) 13(2):155. doi:10.1097/MOT.0b013e3282f97842

10. Rood PP, Buhler LH, Bottino R, Trucco M, Cooper DK. Pig-to-nonhuman primate islet xenotransplantation: a review of current problems. Cell Transplant (2006) 15(2):89. doi:10.3727/000000006783982052

11. Dufrane D, Gianello P. Pig islet xenotransplantation into non-human primate model. Transplantation (2008) 86(6):753. doi:10.1097/TP.0b013e3181840f55

12. Prabhakaran S, Hering BJ. What strain of pig should be used? Xenotransplantation (2008) 15(2):83. doi:10.1111/j.1399-3089.2008.00456.x

13. Thompson P, Badell IR, Lowe M, Turner A, Cano J, Avila J, et al. Alternative immunomodulatory strategies for xenotransplantation: CD40/154 pathway-sparing regimens promote xenograft survival. Am J Transplant (2012) 12(7):1765. doi:10.1111/j.1600-6143.2012.04031.x

14. Dufrane D, Goebbels RM, Gianello P. Alginate macroencapsulation of pig islets allows correction of streptozotocin-induced diabetes in primates up to 6 months without immunosuppression. Transplantation (2010) 90(10):1054. doi:10.1097/TP.0b013e3181f6e267

15. Elliott RB, Escobar L, Tan PL, Muzina M, Zwain S, Buchanan C. Live encapsulated porcine islets from a type 1 diabetic patient $9.5 \mathrm{yr}$ after xenotransplantation. Xenotransplantation (2007) 14(2):157. doi:10.1111/j.1399-3089.2007. 00384.x

16. Hering BJ, Wijkstrom M, Graham ML, Hårdstedt M, Aasheim TC, Jie T, et al. Prolonged diabetes reversal after intraportal xenotransplantation of wild-type porcine islets in immunosuppressed nonhuman primates. Nat Med (2006) 12(3):301. doi:10.1038/nm1369

17. Otonkoski T, Ustinov J, Rasilainen S, Kallio E, Korsgren O, Hayry P. Differentiation and maturation of porcine fetal islet cells in vitro and after transplantation. Transplantation (1999) 68(11):1674. doi:10.1097/00007890-199912150-00010

18. Tan C, Tuch BE, Tu J, Brown SA. Role of NADH shuttles in glucoseinduced insulin secretion from fetal beta-cells. Diabetes (2002) 51(10):2989. doi:10.2337/diabetes.51.10.2989

19. Korsgren O, Jansson L, Eizirik D, Andersson A. Functional and morphological differentiation of fetal porcine islet-like cell clusters after transplantation into nude mice. Diabetologia (1991) 34(6):379. doi:10.1007/BF00403174

20. Bogdani M, Suenens K, Bock T, Pipeleers-Marichal M, In't Veld P, Pipeleers D. Growth and functional maturation of beta-cells in implants of endocrine cells purified from prenatal porcine pancreas. Diabetes (2005) 54(12):3387. doi:10.2337/diabetes.54.12.3387

21. Sandler S, Andersson A, Eizirik DL, Hellerström C, Espevik T, Kulseng B, et al. Assessment of insulin secretion in vitro from microencapsulated fetal porcine islet-like cell clusters and rat, mouse, and human pancreatic islets. Transplantation (1997) 63(12):1712. doi:10.1097/00007890-199706270-00002

22. Hardikar AA, Wang XY, Williams LJ, Kwok J, Wong R, Yao M, et al. Functional maturation of fetal porcine beta-cells by glucagon-like peptide 1 and cholecystokinin. Endocrinology (2002) 143(9):3505. doi:10.1210/en.2001211344

23. Söderlund J, Wennberg L, Castaños-Velez E, Biberfeld P, Zhu S, Tibell A, et al. Fetal porcine islet-like cell clusters transplanted to cynomolgus monkeys: an immunohistochemical study. Transplantation (1999) 67(6):784. doi:10.1097/ 00007890-199903270-00002 
24. Korbutt GS, Elliott JF, Ao Z, Smith DK, Warnock GL, Rajotte RV. Large scale isolation, growth, and function of porcine neonatal islet cells. J Clin Invest (1996) 97(9):2119. doi:10.1172/JCI118649

25. Dufrane D, Gianello P. Pig islets for clinical islet xenotransplantation. Curr Opin Nephrol Hypertens (2009) 18(6):495. doi:10.1097/MNH.0b013e328331a8e3

26. Trivedi N, Hollister-Lock J, Lopez-Avalos MD, O’Neil JJ, Keegan M, BonnerWeir S, et al. Increase in beta-cell mass in transplanted porcine neonatal pancreatic cell clusters is due to proliferation of beta-cells and differentiation of duct cells. Endocrinology (2001) 142(5):2115. doi:10.1210/en.142.5.2115

27. Yoon KH, Quickel RR, Tatarkiewicz K, Ulrich TR, Hollister-Lock J, Trivedi $\mathrm{N}$, et al. Differentiation and expansion of beta cell mass in porcine neonatal pancreatic cell clusters transplanted into nude mice. Cell Transplant (1999) 8(6):673.

28. Weir GC, Quickel RR, Yoon KH, Tatarkiewicz K, Ulrich TR, Hollister-Lock J, et al. Porcine neonatal pancreatic cell clusters (NPCCs): a potential source of tissue for islet transplantation. Ann Transplant (1997) 2(3):63.

29. Nielsen TB, Yderstraede KB, Schroder HD, Holst JJ, Brusgaard K, BeckNielsen H. Functional and immunohistochemical evaluation of porcine neonatal islet-like cell clusters. Cell Transplant (2003) 12(1):13. doi:10.3727/ 000000003783985142

30. Omori T, Nishida T, Komoda H, Fumimoto Y, Ito T, Sawa Y, et al. A study of the xenoantigenicity of neonatal porcine islet-like cell clusters (NPCC) and the efficiency of adenovirus-mediated DAF (CD55) expression. Xenotransplantation (2006) 13(5):455. doi:10.1111/j.1399-3089.2006.00335.x

31. Vizzardelli C, Molano RD, Pileggi A, Berney T, Cattan P, Fenjves ES, et al. Neonatal porcine pancreatic cell clusters as a potential source for transplantation in humans: characterization of proliferation, apoptosis, xenoantigen expression and gene delivery with recombinant AAV. Xenotransplantation (2002) 9(1):14. doi:10.1034/j.1399-3089.2002.0o128.x

32. Cooper DK, Hara H, Ezzelarab M, Bottino R, Trucco M, Phelps C, et al. The potential of genetically-engineered pigs in providing an alternative source of organs and cells for transplantation. J Biomed Res (2013) 27(4):249. doi:10.7555/JBR.27.20130063

33. Casu A, Bottino R, Balamurugan AN, Hara H, van derWindt DJ, Campanile N, et al. Metabolic aspects of pig-to-monkey (Macaca fascicularis) islet transplantation: implications for translation into clinical practice. Diabetologia (2008) 51(1):120. doi:10.1007/s00125-007-0844-4

34. Thompson P, Cardona K, Russell M, Badell IR, Shaffer V, Korbutt G, et al. CD40-specific costimulation blockade enhances neonatal porcine islet survival in nonhuman primates. Am J Transplant (2011) 11(5):947. doi:10.1111/j.16006143.2011.03509.x

35. van derWindt DJ, Bottino R, Casu A, Campanile N, Smetanka C, He J, et al. Long-term controlled normoglycemia in diabetic non-human primates after transplantation with hCD46 transgenic porcine islets. Am J Transplant (2009) 9(12):2716. doi:10.1111/j.1600-6143.2009.02850.x

36. Ricordi C, Socci C, Davalli AM, Staudacher C, Baro P, Vertova A, et al. Isolation of the elusive pig islet. Surgery (1990) 107(6):688.

37. Yonekawa Y, Matsumoto S, Okitsu T, Arata T, Iwanaga Y, Noguchi H, et al. Effective islet isolation method with extremely high islet yields from adult pigs. Cell Transplant (2005) 14(10):757. doi:10.3727/000000005783982512

38. Dufrane D, Goebbels RM, Fdilat I, Guiot Y, Gianello P. Impact of porcine islet size on cellular structure and engraftment after transplantation: adult versus young pigs. Pancreas (2005) 30(2):138. doi:10.1097/01.mpa.0000147083. $62501.4 \mathrm{e}$

39. White SA, Hughes DP, Contractor HH, London NJ. A comparison of cross sectional surface area densities between adult and juvenile porcine islets of Langerhans. Horm Metab Res (1999) 31(9):519. doi:10.1055/s-2007-978787

40. Jay TR, Heald KA, Carless NJ, Topham DE, Downing R. The distribution of porcine pancreatic beta-cells at ages 5, 12 and 24 weeks. Xenotransplantation (1999) 6(2):131. doi:10.1034/j.1399-3089.1999.00009.x

41. Dufrane D, Goebbels RM, Guiot Y, Gianello P. Is the expression of Galalpha1,3Gal on porcine pancreatic islets modified by isolation procedure? Transplant Proc (2005) 37(1):455. doi:10.1016/j.transproceed.2004.12.161

42. Kirchhof N, Hering BJ, Geiss V, Federlin K, Bretzel RG. Evidence for breeddependent differences in porcine islets of Langerhans. Transplant Proc (1994) 26(2):616.

43. Ulrichs K, Bosss M, Heiser A, Eckstein V, Wacker H-H, Thiede A. Histomorphological characteristics of the porcine pancreas as a basis for the isolation of islets of Langerhans. Xenotransplantation (1995) 2(3):176. doi:10.1111/j.13993089.1995.tb00091.x

44. Heiser A, Ulrichs K, Muller-Ruchholtz W. Influence of porcine strain, age, and $\mathrm{pH}$ of the isolation medium on porcine pancreatic islet isolation success. Transplant Proc (1994) 26(2):618.

45. Kim JH, Kim HI, Lee KW, Yu JE, Kim SH, Park HS, et al. Influence of strain and age differences on the yields of porcine islet isolation: extremely high islet yields from SPF CMS miniature pigs. Xenotransplantation (2007) 14(1):60. doi:10.1111/j.1399-3089.2006.00364.x

46. Rajotte RV. Isolation and assessment of islet quality. Xenotransplantation (2008) 15(2):93. doi:10.1111/j.1399-3089.2008.00459.x

47. Kim HI, Lee SY, Jin SM, Kim KS, Yu JE, Yeom SC, et al. Parameters for successful pig islet isolation as determined using 68 specific-pathogen-free miniature pigs. Xenotransplantation (2009) 16(1):11. doi:10.1111/j.1399-3089.2008.00504.x

48. Dufrane D, D'Hoore W, Goebbels RM, Saliez A, Guiot Y, Gianello P. Parameters favouring successful adult pig islet isolations for xenotransplantation in pig-to-primate models. Xenotransplantation (2006) 13(3):204. doi:10.1111/j. 1399-3089.2006.00275.x

49. Kin T, Shapiro AM. Surgical aspects of human islet isolation. Islets (2010) 2(5):265. doi:10.4161/isl.2.5.13019

50. Mundwiler KE, Lamberti FV, Hill RS. Rapid and inexpensive method for the quantitative assessment of donor pancreata for islet isolation. Transplant Proc (1994) 26(6):3427.

51. Krickhahn M, Buhler C, Meyer T, Thiede A, Ulrichs K. The morphology of islets within the porcine donor pancreas determines the isolation result: successful isolation of pancreatic islets can now be achieved from young market pigs. Cell Transplant (2002) 11(8):827.

52. Gazda LS, Adkins H, Bailie JA, Byrd W, Circle L, Conn B, et al. The use of pancreas biopsy scoring provides reliable porcine islet yields while encapsulation permits the determination of microbiological safety. Cell Transplant (2005) 14(7):427. doi:10.3727/000000005783982846

53. Anazawa T, Balamurugan AN, Matsumoto S, Lafreniere SA, O’Brien TD, Sutherland DE, et al. Rapid quantitative assessment of the pig pancreas biopsy predicts islet yield. Transplant Proc (2010) 42(6):2036. doi:10.1016/j. transproceed.2010.05.113

54. Stadlbauer V, Schaffellner S, Iberer F, Lackner C, Liegl B, Zink B, et al. Occurrence of apoptosis during ischemia in porcine pancreas islet cells. Int J Artif Organs (2003) 26(3):205.

55. Goto M, Imura T, Inagaki A, Ogawa N, Yamaya H, Fujimori K, et al. The impact of ischemic stress on the quality of isolated pancreatic islets. Transplant Proc (2010) 42(6):2040. doi:10.1016/j.transproceed.2010.05.101

56. Brandhorst D, Brandhorst H, Hering BJ, Federlin K, Bretzel RG. Islet isolation from the pancreas of large mammals and humans: 10 years of experience. Exp Clin Endocrinol Diabetes (1995) 103(Suppl 2):3. doi:10.1055/s-00291211386

57. Ricordi C, Finke EH, Lacy PE. A method for the mass isolation of islets from the adult pig pancreas. Diabetes (1986) 35(6):649. doi:10.2337/diab.35.6.649

58. Nielsen TB, Yderstraede KB, Beck-Nielsen H. Isolation, transplantation, and functional studies of adult porcine islets of Langerhans. Comp Med (2002) 52(2):127

59. O'Gorman D, Kin T, Imes S, Pawlick R, Senior P, Shapiro AM. Comparison of human islet isolation outcomes using a new mammalian tissue-free enzyme versus collagenase NB-1. Transplantation (2010) 90(3):255. doi:10.1097/TP. 0b013e3181e117ce

60. Jin SM, Shin JS, Kim KS, Gong CH, Park SK, Kim JS, et al. Islet isolation from adult designated pathogen-free pigs: use of the newer bovine nervous tissue-free enzymes and a revised donor selection strategy would improve the islet graft function. Xenotransplantation (2011) 18(6):369. doi:10.1111/j.13993089.2011.00677.x

61. Gray DW, Sudhakaran N, Titus TT, McShane P, Johnson P. Development of a novel digestion chamber for human and porcine islet isolation. Transplant Proc (2004) 36(4):1135. doi:10.1016/j.transproceed.2004.04.050

62. Stiegler P, Stadlbauer V, Hackl F, Schaffellner S, Iberer F, Greilberger J, et al. Prevention of oxidative stress in porcine islet isolation. J Artif Organs (2010) 13(1):38. doi:10.1007/s10047-010-0488-x

63. Li S, Sakai T, Suzuki Y, Goto T, Tanaka T, Yoshikawa T, et al. Improved quantity and in vivo function of islets isolated by reduced pressure-controlled injection of collagenase in a rat model. Cell Transplant (2007) 16(5):539. 
64. Carter JD, Dula SB, Corbin KL, Wu R, Nunemaker CS. A practical guide to rodent islet isolation and assessment. Biol Proced Online (2009) 11:3. doi:10.1007/s12575-009-9021-0

65. Marchetti P, Finke EH, Gerasimidi-Vazeou A, Falqui L, Scharp DW, Lacy PE. Automated large-scale isolation, in vitro function and xenotransplantation of porcine islets of Langerhans. Transplantation (1991) 52(2):209. doi:10.1097/00007890-199108000-00005

66. Toso C, Brandhorst D, Oberholzer J, Triponez F, Buhler L, Morel P. Isolation of adult porcine islets of Langerhans. Cell Transplant (2000) 9(3):297.

67. Min T, Yi L, Chao Z, Haitao Z, Wei W, Liang Y, et al. Superiority of visipaque (iodixanol)-controlled density gradient over Ficoll-400 in adult porcine islet purification. Transplant Proc (2010) 42(5):1825. doi:10.1016/j.transproceed. 2010.01.068

68. van der Burg MP, Graham JM. Iodixanol density gradient preparation in University of Wisconsin solution for porcine islet purification. ScientificWorldJournal (2003) 3:1154. doi:10.1100/tsw.2003.107

69. Mita A, Ricordi C, Miki A, Barker S, Khan A, Alvarez A, et al. Purification method using iodixanol (OptiPrep)-based density gradient significantly reduces cytokine chemokine production from human islet preparations, leading to prolonged beta-cell survival during pretransplantation culture. Transplant Proc (2009) 41(1):314. doi:10.1016/j.transproceed.2008.10.059

70. Rijkelijkhuizen JK, van der Burg MP, Tons A, Terpstra OT, Bouwman E. Pretransplant culture selects for high-quality porcine islets. Pancreas (2006) 32(4):403. doi:10.1097/01.mpa.0000220866.87658.b2

71. Ekser B, Cooper DK. Overcoming the barriers to xenotransplantation: prospects for the future. Expert Rev Clin Immunol (2010) 6(2):219. doi:10. 1586/eci.09.81

72. Scalea J, Hanecamp I, Robson SC, Yamada K. T-cell-mediated immunological barriers to xenotransplantation. Xenotransplantation (2012) 19(1):23. doi:10.1111/j.1399-3089.2011.00687.x

73. Nilsson B. The instant blood-mediated inflammatory reaction in xenogeneic islet transplantation. Xenotransplantation (2008) 15(2):96. doi:10.1111/j.13993089.2008.00460.x

74. Johansson H, Lukinius A, Moberg L, Lundgren T, Berne C, Foss A, et al. Tissue factor produced by the endocrine cells of the islets of Langerhans is associated with a negative outcome of clinical islet transplantation. Diabetes (2005) 54(6):1755. doi:10.2337/diabetes.54.6.1755

75. Goto M, Tjernberg J, Dufrane D, Elgue G, Brandhorst D, Ekdahl KN, et al. Dissecting the instant blood-mediated inflammatory reaction in islet xenotransplantation. Xenotransplantation (2008) 15(4):225. doi:10.1111/j.1399-3089. 2008.00482.x

76. Marigliano M, Bertera S, Grupillo M, Trucco M, Bottino R. Pig-to-nonhuman primates pancreatic islet xenotransplantation: an overview. Curr Diab Rep (2011) 11(5):402. doi:10.1007/s11892-011-0213-z

77. Nyqvist D, Kohler M, Wahlstedt H, Berggren PO. Donor islet endothelial cells participate in formation of functional vessels within pancreatic islet grafts. Diabetes (2005) 54(8):2287. doi:10.2337/diabetes.54.8.2287

78. Rayat GR, Rajotte RV, Hering BJ, Binette TM, Korbutt GS. In vitro and in vivo expression of Galalpha- $(1,3) \mathrm{Gal}$ on porcine islet cells is age dependent. J Endocrinol (2003) 177(1):127. doi:10.1677/joe.0.1770127

79. Komoda H, Miyagawa S, Kubo T, Kitano E, Kitamura H, Omori T, et al. A study of the xenoantigenicity of adult pig islets cells. Xenotransplantation (2004) 11(3):237. doi:10.1111/j.1399-3089.2004.00121.x

80. Gill RG, Wolf L, Daniel D, Coulombe M. CD4+ T cells are both necessary and sufficient for islet xenograft rejection. Transplant Proc (1994) 26(3):1203.

81. Olack BJ, Jaramillo A, Benshoff ND, Kaleem Z, Swanson CJ, Lowell JA, et al. Rejection of porcine islet xenografts mediated by CD4+ T cells activated through the indirect antigen recognition pathway. Xenotransplantation (2002) 9(6):393. doi:10.1034/j.1399-3089.2002.01070.x

82. Koulmanda M, Laufer TM, Auchincloss H Jr, Smith RN. Prolonged survival of fetal pig islet xenografts in mice lacking the capacity for an indirect response. Xenotransplantation (2004) 11(6):525. doi:10.1111/j.1399-3089.2004.00174.x

83. Kirchhof N, Shibata S, Wijkstrom M, Kulick DM, Salerno CT, Clemmings $\mathrm{SM}$, et al. Reversal of diabetes in non-immunosuppressed rhesus macaques by intraportal porcine islet xenografts precedes acute cellular rejection. Xenotransplantation (2004) 11(5):396. doi:10.1111/j.1399-3089.2004.00157.x

84. Lindeborg E, Kumagai-Braesch M, Moller E. Phenotypic and functional characterization of human $\mathrm{T}$ cell clones indirectly activated against adult pig islet cells. Xenotransplantation (2006) 13(1):41. doi:10.1111/j.1399-3089.2005. 00257.x

85. Trikudanathan S, Sayegh MH. The evolution of the immunobiology of costimulatory pathways: clinical implications. Clin Exp Rheumatol (2007) 25(5 Suppl 46):S12.

86. Sakata N, Sumi S, Yoshimatsu G, Goto M, Egawa S, Unno M. Encapsulated islets transplantation: past, present and future. World J Gastrointest Pathophysiol (2012) 3(1):19. doi:10.4291/wjgp.v3.i1.19

87. de Vos P, Hamel AF, Tatarkiewicz K. Considerations for successful transplantation of encapsulated pancreatic islets. Diabetologia (2002) 45(2):159. doi:10.1007/s00125-001-0729-x

88. Orlowski T, Sitarek E, Tatarkiewicz K, Sabat M, Antosiak M. Comparison of two methods of pancreas islets immunoisolation. Int J Artif Organs (1997) 20(12):701.

89. Kin T, Iwata H, Aomatsu Y, Ohyama T, Kanehiro H, Hisanaga M, et al. Xenotransplantation of pig islets in diabetic dogs with use of a microcapsule composed of agarose and polystyrene sulfonic acid mixed gel. Pancreas (2002) 25(1):94. doi:10.1097/00006676-200207000-00020

90. Schaffellner S, Stadlbauer V, Stiegler P, Hauser O, Halwachs G, Lackner C, et al. Porcine islet cells microencapsulated in sodium cellulose sulfate. Transplant Proc (2005) 37(1):248. doi:10.1016/j.transproceed.2005.01.042

91. Antosiak-Iwanska M, Sitarek E, Sabat M, Godlewska E, Kinasiewicz J, Werynski A. Isolation, banking, encapsulation and transplantation of different types of Langerhans islets. Pol Arch Med Wewn (2009) 119(5):311.

92. Lembert N, Wesche J, Petersen P, Doser M, Zschocke P, Becker HD, et al. Encapsulation of islets in rough surface, hydroxymethylated polysulfone capillaries stimulates VEGF release and promotes vascularization after transplantation. Cell Transplant (2005) 14(2-3):97. doi:10.3727/000000005783983232

93. Dufrane D, Goebbels RM, Saliez A, Guiot Y, Gianello P. Six-month survival of microencapsulated pig islets and alginate biocompatibility in primates: proof of concept. Transplantation (2006) 81(9):1345. doi:10.1097/01.tp.0000208610. 75997.20

94. Zhai C, Yu L, Zhu H, Tian M, Xiaogang Z, Bo W. Porcine CTLA4-Ig prolong islet xenografts in rats by downregulating the direct pathway of T-cell activation. Xenotransplantation (2011) 18(1):40. doi:10.1111/j.1399-3089.2011. 00627.x

95. Tian M, Lv Y, Zhai C, Zhu H, Yu L, Wang B. Alternative immunomodulatory strategies for xenotransplantation: CD80/CD86-CTLA4 pathwaymodified immature dendritic cells promote xenograft survival. PLoS One (2013) 8(7):e69640. doi:10.1371/journal.pone.0069640

96. Forster E, Krenger W, Joergensen J, Hof R, Geha RS, Hollander GA. Contribution of CD40-CD154-mediated costimulation to an alloresponse in vivo. Transplantation (1999) 67(9):1284. doi:10.1097/00007890-19990515000016

97. Yamada A, Salama AD, Sayegh MH. The role of novel T cell costimulatory pathways in autoimmunity and transplantation. JAm Soc Nephrol (2002) 13(2):559.

98. Cardona K, Korbutt GS, Milas Z, Lyon J, Cano J, Jiang W, et al. Long-term survival of neonatal porcine islets in nonhuman primates by targeting costimulation pathways. Nat Med (2006) 12(3):304. doi:10.1038/nm1375

99. Schuler W, Bigaud M, Brinkmann V, Di Padova F, Geisse S, Gram H, et al. Efficacy and safety of ABI793, a novel human anti-human CD154 monoclonal antibody, in cynomolgus monkey renal allotransplantation. Transplantation (2004) 77(5):717. doi:10.1097/01.TP.0000116563.72763.83

100. d'Apice AJ, Cowan PJ. Gene-modified pigs. Xenotransplantation (2008) 15(2):87. doi:10.1111/j.1399-3089.2008.00457.x

101. Nagaraju S, Bottino R, Wijkstrom M, Hara H, Trucco M, Cooper DK. Islet xenotransplantation from genetically engineered pigs. Curr Opin Organ Transplant (2013) 18(6):695. doi:10.1097/MOT.0000000000000020

102. Yeom HJ, Koo OJ, Yang J, Cho B, Hwang JI, Park SJ, et al. Generation and characterization of human heme oxygenase-1 transgenic pigs. PLoS One (2012) 7(10):e46646. doi:10.1371/journal.pone.0046646

103. Diamond LE, Quinn CM, Martin MJ, Lawson J, Platt JL, Logan JS. A human CD46 transgenic pig model system for the study of discordant xenotransplantation. Transplantation (2001) 71(1):132. doi:10.1097/00007890-20010115000021

104. Liu D, Kobayashi T, Onishi A, Furusawa T, Iwamoto M, Suzuki S, et al. Relation between human decay-accelerating factor (hDAF) expression in pig cells and inhibition of human serum anti-pig cytotoxicity: value of highly 
expressed hDAF for xenotransplantation. Xenotransplantation (2007) 14(1):67. doi:10.1111/j.1399-3089.2006.00365.x

105. Le Bas-Bernardet S, Tillou X, Poirier N, Dilek N, Chatelais M, Devallière J, et al. Xenotransplantation of galactosyl-transferase knockout, CD55, CD59, CD39, and fucosyl-transferase transgenic pig kidneys into baboons. Transplant Proc (2011) 43(9):3426. doi:10.1016/j.transproceed.2011.09.024

106. Klymiuk N, van Buerck L, Bähr A, Offers M, Kessler B, Wuensch A, et al. Xenografted islet cell clusters from INSLEA29Y transgenic pigs rescue diabetes and prevent immune rejection in humanized mice. Diabetes (2012) 61(6):1527. doi:10.2337/db11-1325

107. Ramsoondar J, Vaught T, Ball S, Mendicino M, Monahan J, Jobst P, et al. Production of transgenic pigs that express porcine endogenous retrovirus small interfering RNAs. Xenotransplantation (2009) 16(3):164. doi:10.1111/j.13993089.2009.00525.x

108. Semaan M, Kaulitz D, Petersen B, Niemann H, Denner J. Long-term effects of PERV-specific RNA interference in transgenic pigs. Xenotransplantation (2012) 19(2):112. doi:10.1111/j.1399-3089.2012.00683.x

109. Merani S, Toso C, Emamaullee J, Shapiro AM. Optimal implantation site for pancreatic islet transplantation. BrJ Surg (2008) 95(12):1449. doi:10.1002/bjs. 6391

110. van der Windt DJ, Echeverri GJ, Ijzermans JN, Cooper DK. The choice of anatomical site for islet transplantation. Cell Transplant (2008) 17(9):1005. doi:10.3727/096368908786991515

111. Dufrane D, Steenberghe M, Goebbels RM, Saliez A, Guiot Y, Gianello P. The influence of implantation site on the biocompatibility and survival of alginate encapsulated pig islets in rats. Biomaterials (2006) 27(17):3201. doi:10.1016/j.biomaterials.2006.01.028

112. Eventov-Friedman S, Tchorsh D, Katchman H, Shezen E, Aronovich A, Hecht G, et al. Embryonic pig pancreatic tissue transplantation for the treatment of diabetes. PLoS Med (2006) 3(7):e215. doi:10.1371/journal.pmed.0030215

113. Menger MD, Yamauchi J, Vollmar B. Revascularization and microcirculation of freely grafted islets of Langerhans. World J Surg (2001) 25(4):509. doi:10.1007/s002680020345

114. Jansson L, Carlsson PO. Graft vascular function after transplantation of pancreatic islets. Diabetologia (2002) 45(6):749. doi:10.1007/s00125-002$0827-4$

115. Johansson U, Rasmusson I, Niclou SP, Forslund N, Gustavsson L, Nilsson B, et al. Formation of composite endothelial cell-mesenchymal stem cell islets: a novel approach to promote islet revascularization. Diabetes (2008) 57(9):2393. doi:10.2337/db07-0981

116. Sakata N, Chan NK, Chrisler J, Obenaus A, Hathout E. Bone marrow cell cotransplantation with islets improves their vascularization and function. Transplantation (2010) 89(6):686. doi:10.1097/TP.0b013e3181cb3e8d
117. Tchorsh-Yutsis D, Hecht G, Aronovich A, Shezen E, Klionsky Y, Rosen C, et al. Pig embryonic pancreatic tissue as a source for transplantation in diabetes: transient treatment with anti-LFA1, anti-CD48, and FTY720 enables longterm graft maintenance in mice with only mild ongoing immunosuppression. Diabetes (2009) 58(7):1585. doi:10.2337/db09-0112

118. Groth CG, Korsgren O, Tibell A, Tollemar J, Möller E, Bolinder J, et al. Transplantation of porcine fetal pancreas to diabetic patients. Lancet (1994) 344(8934):1402. doi:10.1016/S0140-6736(94)90570-3

119. Tan PL. Company profile: tissue regeneration for diabetes and neurological diseases at Living Cell Technologies. Regen Med (2010) 5(2):181. doi:10.2217/ rme.10.4

120. Elliott RB. Towards xenotransplantation of pig islets in the clinic. Curr Opin Organ Transplant (2011) 16(2):195. doi:10.1097/MOT.0b013e3283449dec

121. Yu P, Zhang L, Li SF, Li YP, Cheng JQ, Lu YR, et al. Long-term effects on HEK293 cell line after co-culture with porcine endogenous retrovirus. Transplant Proc (2005) 37(1):496. doi:10.1016/j.transproceed.2004.12.296

122. van derLaan LJ, Lockey C, Griffeth BC, Frasier FS, Wilson CA, Onions DE, et al. Infection by porcine endogenous retrovirus after islet xenotransplantation in SCID mice. Nature (2000) 407(6800):90. doi:10.1038/35024089

123. Valdes-Gonzalez R, Dorantes LM, Bracho-Blanchet E, Rodriguez-Ventura A, White DJ. No evidence of porcine endogenous retrovirus in patients with type 1 diabetes after long-term porcine islet xenotransplantation. J Med Virol (2010) 82(2):331. doi:10.1002/jmv.21655

Conflict of Interest Statement: The authors declare that the research was conducted in the absence of any commercial or financial relationships that could be construed as a potential conflict of interest.

Received: 16 December 2013; paper pending published: 03 February 2014; accepted: 07 March 2014; published online: 24 March 2014.

Citation: Zhu H-T, Wang W-L, Yu L and Wang B (2014) Pig-islet xenotransplantation: recent progress and current perspectives. Front. Surg. 1:7. doi:10.3389/fsurg.2014. 00007

This article was submitted to Visceral Surgery, a section of the journal Frontiers in Surgery.

Copyright (c) 2014 Zhu, Wang, Yu and Wang. This is an open-access article distributed under the terms of the Creative Commons Attribution License (CC $B Y)$. The use, distribution or reproduction in other forums is permitted, provided the original author(s) or licensor are credited and that the original publication in this journal is cited, in accordance with accepted academic practice. No use, distribution or reproduction is permitted which does not comply with these terms. 